\title{
Pengaruh Agency Cost of Free Cash Flow Terhadap Tingkat Konservatisme dan Pengujian Efek Moderasi Kebijakan Hutang, Pendistribusian Kas, Persistensi Kas, dan Tata Kelola Perusahaan
}

\author{
Hendro $^{1}$, Ratna Wardhani ${ }^{*}$ \\ ${ }^{1}$ Fakultas Ekonomi, Universitas Indonesia \\ Jl. Dr. Sumitro Djojohadikusumo (Lkr. Kampus Raya), Depok \\ * Penulis korespondensi; Email: ratnawardhani@yahoo.com
}

\begin{abstract}
ABSTRAK
Penelitian ini bertujuan untuk mengetahui apakah perusahaan tipe-J (agency cost of free cash flow tinggi) akan membuat laporan keuangan yang lebih konservatif dibandingkan perusahaan tipe non-J. Selain itu, penelitian ini melihat pengaruh efek moderasi hutang, dividen, stock repurchase, persistensi kas, dan tata kelola perusahaan dalam mempengaruhi hubungan antara tingkat agency cost of free cash flow dan tingkat konservatisme laporan keuangan perusahaan. Penelitian ini menggunakan dua ukuran konservatisme, yakni konservatisme ukuran akrual dan konservatisme nilai pasar. Sampel penelitian terdiri dari perusahaan manufaktur yang terdaftar di Bursa Efek Indonesia untuk tahun 2007, 2008 dan 2010. Hasil penelitian menunjukkan adanya hubungan positif dan signifikan antara tingkat agency cost of free cash flow dan tingkat konservatisme laporan keuangan perusahaan untuk kedua ukuran konservatisme. Selain itu, penelitian ini mengindikasikan bahwa tidak terdapat pengaruh variabel moderasi atas hubungan kedua variabel tersebut.
\end{abstract}

Kata kunci: Konservatisme, akrual, agency cost of free cash flow, hutang, dividen, stock repurchase, persistensi kas perusahaan, tata kelola perusahaan.

\begin{abstract}
This research investigates whether the J-type firm (high agency cost of free cash flow) provide more conservative financial statements than non J-type firm. Besides, this research also aim to examine the moderating effects of debt, dividend, stock repurchase, cash persistency, and corporate governance on the relationship between the level of agency cost of free cash flow and conservatism level of financial statements. This research uses two measurement of conservatism, namely accrual conservatism and market value conservatism. Research sample includes manufacturing companies listed in the Indonesian Stock Exchange for the year 2007, 2008 and 2010. The result proves that there is a positive and significant relationship between the level of agency cost of free cash flow and the two measurement of conservatism level of financial stataments. However, this research shows that there is no effect of the moderating variables on that relationship.
\end{abstract}

Keywords: Conservatism, accruals, agency cost of free cash flow, debt, dividend, stock repurchase, cash retention, corporate governance.

\section{PENDAHULUAN}

Seiring dengan semakin kompleksnya aktivitas bisnis perusahaan, muncul kebutuhan pemilik perusahaan untuk mempekerjakan pihak yang kompeten dan profesional untuk menjalankan aktivitas operasional. Pemilik perusahaan (principal) mempekerjakan manajer (agent) dan mendelegasikan beberapa otoritas pengambilan keputusan agar manajer dapat bertindak sebagai perpanjangan tangan dari sang pemilik (Jensen and Meckling, 1976). Akan tetapi kondisi tersebut dapat menjadi tidak ideal apabila manajer bersifat oportunistik untuk memaksimumkan kepenting- 
annya dan mengesampingkan kepentingan pemilik. Dalam kondisi dimana manajer sebagai agen bertindak oportunistik dan tidak mengoptimalkan pencapaian kepentingan prinsipal, maka muncul permasalahan keagenan (agency problem). Untuk mengatasi permasalahan keagenan tersebut, prinsipal akan melakukan kebijakankebijakan yang terkait dengan fungsi pengawasan (monitoring) dan pengikatan (bounding). Pelaksanaan kebijakan-kebijakan untuk meminimalisasi permasalahan keagenan tersebut tentunya akan menimbulkan biaya yang harus ditanggung oleh perusahaan, yang disebut sebagai biaya keagenan (agency cost). Oleh sebab itu, biaya keagenan merupakan biaya yang dikeluarkan perusahaan untuk mencapai titik temu atas perbedaan kepentingan antara agen dan prinsipal.

Salah satu pemicu utama yang menyebabkan munculnya agency problem adalah dimilikinya free cash flow (FCF) yang substantif dalam perusahaan. FCF didefinisikannya sebagai kelebihan arus kas setelah digunakan untuk membiayai semua proyek yang memiliki NPV positif ketika didiskon (discounted) pada cost of capital yang relevan. Permasalahan keagenan dalam konteks dimilikinya FCF secara berlebih oleh perusahaan timbul karena adanya perbedaan kepentingan atas FCF tersebut, dimana prinsipal memiliki kepentingan untuk menikmati FCF tersebut dalam bentuk deviden, sedangkan manajer dapat cenderung bersifat oportunistik dengan menahan atau mempergunakan FCF tersebut untuk mengambil kebijakan-kebijakan atau projek-projek yang memberikan keuntungan baginya, dan dengan mengorbankan kepentingan pemilik. Untuk meminimalisasi tersebut perusahaan harus mengeluarkan biaya keagenan yang kerap disebut agency cost of free cash flow (Jensen 1986).

Jensen (1986, 1989) menyatakan bahwa manajer pada perusahaan yang memiliki FCF tinggi namun pertumbuhannya rendah, yang lebih lanjut akan disebut perusahaan "tipe-J", cenderung terlibat dalam aktivitas yang bersifat tidak menguntungkan perusahaan (non-value-maximizing). Manajer pada perusahaan tipe ini cenderung bersifat oportunistik dan terlibat dalam aktivitas yang bersifat merusak value perusahaan dengan melakukan investasi berlebihan (overinvest) dan menyalahgunakan modal perusahaan. Hal ini didukung oleh penelitian Shleifer dan Vishny (1997) yang menunjukkan bahwa manajer cenderung menahan dana di bawah kendalinya agar dapat meningkatkan kompensasi dan melakukan aktivitas yang terkait dengan management entrenchment. Dengan demikian dapat disimpulkan bahwa agency cost of free cash flow akan lebih tinggi pada perusahaan tipe-J.
Salah satu mekanisme yang dapat diterapkan untuk memitigasi eksposur terkait tindakan ekspropriasi yang dilakukan manajer pada perusahaan tipe-J adalah dengan menerapkan praktik konservatisme yang bersifat kondisional (conditional conservatism). Konservatisme sendiri didefinisikan oleh Watts (2003a) sebagai prinsip kehati-hatian dalam pelaporan keuangan dimana perusahaan tidak terburu-buru dalam mengakui dan mengukur aktiva dan laba serta segera mengakui kerugian dan hutang yang mempunyai kemungkinan yang terjadi. Terdapat dua jenis konservatisme yaitu konservatisme yang bersifat kondisional dan konservatisme yang bersifat tidak kondisional. Konservatisme yang bersifat tidak kondisional merupakan konservatisme akuntansi yang secara bias melaporkan nilai buku equitas yang rendah. Dalam hal ini perusahaan disebut konservatif apabila menunda pengakuan pendapatan pada suatu titik waktu atau secara periodik mengurangi labanya secara konstan independen terhadap tingkat laba atau rugi tahun berjalan. Sedangkan konservatiesme kondisional lebih menekankan pada ketepatan waktu pengakuan kerugian (timeliness of loss recognition) dimana pengurangan pada laba akuntansi merupakan refleksi dari economic loss yang tengah terjadi (bersifat news dependent). Berdasarkan definisi tersebut maka konservatisme yang bersifat kondisional yang lebih mencerminkan kualitas laporan keuangan yang lebih tinggi karena mencerminkan nilai ekonomis perusahaan yang sesungguhnya. Oleh karena itu, untuk memitigasi risiko ekspropriasi perusahaan tipe-J akan melakukan monitoring melalui laporan keuangan yang berkualitas yaitu yang menerapkan konservatisme yang bersifat kondisional.

Penelitian sebelumnya membuktikan bahwa praktik konservatisme mengalami perkembangan yang sangat pesat dalam merespon kebutuhan dari pengguna laporan keuangan akan laporan keuangan yang berkualitas. Laporan keuangan yang bersifat konservatif dapat menjadi mekanisme pengawasan kinerja manajer karena laporan keuangan yang bersifat konservatif akan mencerminkan nilai ekonomis perusahaan yang sesungguhnya (Watts, 2003b; Holthausen dan Watts, 2001; LaFond dan Roychowdhury, 2008; LaFond dan Watts, 2008). Hal ini senada dengan penelitian Ball dan Shivakumar (2006) yang mengemukakan bahwa dengan adanya pelaporan keuangan secara konservatif akan menjadi disinsentif bagi manajer yang oportunis, dikarenakan kerugian sebagai dampak dari investasi pada proyek yang memiliki NPV negatif akan dibebankan pada periode tersebut. Selain itu, kebijakan hutang pun dapat menjadi mekanisme kontrol atas per- 
masalahan keagenan tersebut. Jensen (1986) mengemukakan bahwa hutang menimbulkan tuntutan untuk melakukan pembayaran sejumlah kas untuk tiap periode, yang lebih lanjut akan menurunkan kelebihan kas yang terdapat dalam perusahaan. Dengan demikian dapat mengurangi kemungkinan adanya ekspropriasi yang dilakukan oleh manajer

Mekanisme lain yang dapat memitigasi agency cost of free cash flow adalah kebijakan pendistribusian kas yang diterapkan perusahaan, yakni pembagian dividen ataupun stock repurchase. Dengan adanya kebijakan pendistribusian kas kepada shareholder, maka sumber daya perusahaan yang berada di bawah kendali manajer akan berkurang. Hal ini tentu akan mendorong manajer untuk lebih selektif dalam memutuskan kebijakan investasi sehingga akan mengurangi penggunaan dana untuk investasi yang bersifat tidak menguntungkan. Hal senada diungkapkan oleh Easterbrook (1984) dan Kose John dan Anzhela Knyazevan (2006) yang menyatakan bahwa dividen dapat mengurangi agency cost of free cash flow. Selain itu, dengan adanya peningkatan pada dividend payout ratio, maka dapat mendorong manajer untuk mencari pendanaan dari luar untuk membiayai investasinya, yang lebih lanjut dapat mengurangi eksposur penggunaan FCF yang bersifat non-value maximizing (Crutchley and Hansen, 1989). Dan terkait dengan stock repurchase, Grullon dan Michaely (2004) menemukan bahwa cadangan kas dalam balance sheet perusahaan yang melakukan stock repurchase turun secara signifikan, yang mengindikasikan berkurangnya sumber daya perusahaan (FCF) yang dapat disalahgunakan oleh manajer.

Persistensi kas pun dapat mempengaruhi agency cost of free cash flow, yang mana akan lebih tinggi pada perusahaan yang cenderung menahan kelebihan kas-nya. Penelitian yang dilakukan oleh Dechow, Richardson, dan Sloan (2008) membuktikan bahwa perusahaan yang persisten menahan kas akan mengalami penurunan ROA di masa mendatang sebagai dampak dari penurunan marginal return dari investasi baru dan sebagai dampak dari praktik overinvestment yang dilakukan oleh manajer.

Mekanisme terakhir yang dapat diterapkan perusahaan untuk mengatasi permasalahan keagenan tersebut adalah tata kelola perusahaan. Dittmar, Mahrt-Smith, and Servaes (2003) mengungkapkan bahwa tata kelola perusahaan yang baik dapat berperan sebagai mekanisme efektif untuk mengatasi eksposur dari agency cost of free cash flow. Adapun La Porta et al. (2000) mendifinisikan tata kelola perusahaan sebagai suatu mekanisme yang memampukan outside investor untuk melindungi kepentingan mereka dari eksposur ekspropriasi yang dilakukan oleh insider, atau dalam konteks ini adalah manajer.

Sebagaimana telah dipaparkan di atas, terdapat lima mekanisme yang dapat diterapkan perusahaan untuk memitigasi eksposur dari agency cost of free cash flow, yakni (1) Konservatisme, (2) Kebijakan hutang, (3) Kebijakan pendistribusian kas, (4) Kebijakan persistensi kas, dan (5) Tata kelola perusahaan. Dalam penelitian ini, peneliti akan memfokuskan pada satu mekanisme, yakni konservatisme. Hal tersebut didasarkan pada pernyataan Jensen (1986), yang mengungkapkan bahwa konservatisme merupakan mekanisme yang dapat secara ex-ante mengontrol keputusan investasi dan secara ex-post memfasilitasi pengawasan pengambilan keputusan manajemen. Oleh karena itu, konservatisme dianggap sebagai mekanisme efektif untuk membantu memitigasi eksposur terkait penurunan value perusahaan ataupun ekspropriasi kekayaan shareholder yang timbul sebagai akibat dari adanya agency cost of free cash flow.

Kembali ke pernyataan Jensen sebelumnya yang mengemukakan bahwa agency cost of free cash flow akan lebih tinggi pada perusahaan tipeJ, dapat disimpulkan bahwa shareholder pada perusahaan tersebut tentulah akan menuntut pelaporan yang bersifat lebih konservatif dibandingkan dengan shareholder pada perusahaan tipe non-J, sehingga laporan keuangan perusahaan tipe-J akan lebih konservatif. Berdasarkan hal tersebut penelitian ini memiliki dua tujuan, yakni (1) Menganalisis perbedaan tingkat konservatisme antara perusahaan tipe-J dengan perusahaan tipe non-J;1 dan (2) Menganalisis pengaruh faktorfaktor lain seperti hutang, pendistribusian kas, kebijakan persistensi kas, dan tata kelola perusahaan terhadap hubungan positif tingkat agency cost of free cash flow dan tingkat konservatisme laporan keuangan perusahaan.

Dalam konteks Indonesia dimana risiko ekspropriasi yang tinggi akibat adanya kepemilikan yang terkonsentrasi dan masih rendahnya kualitas pelaporan keuangan perusahaan, maka penelitian terhadap bagaimana pengaruh biaya keagenan terhadap konservatisme sebagai salah satu dimensi dari kualitas laporan keuangan menjadi sangat penting. Penelitian terdahulu juga telah meneliti pengaruh mekanisme CG baik level institusional (negara) seperti sistem legal, litigasi,

\footnotetext{
${ }^{1}$ Perusahaan tipe-J adalah perusahaan yang memiliki free cash flow tinggi, namun pertumbuhannya rendah. Adapun perusahaan tipe-J ini oleh Jensen dikatakan memiliki agency cost of free cash flow yang tinggi.
} 
perpajakan, dan lain-lain (Ball et al., 2003, Bushman and Piotroski 2006, Wardhani et al. 2015), dan level perusahaan seperti kebijakan dividend, mekanisme governance, komposisi dewan, dan lain-lain (Ahmed et al. 2002, Wardhani et al. 2015, Beekes et al. 2004) terhadap konservatisme. Namun demikian, penelitian sebelumnya belum meneliti secara spesifik pengaruh konflik keagenan yang dipicu oleh adanya free cash flow secara substansial pada perusahaan terhadap tingkat konservatisme, terutama di Indonesia. Atas dasar pemikiran inilah peneliti mengembangkan kerangka penulisan terkait dengan konservatisme pelaporan keuangan sebagai mekanisme pengendalian agency cost of free cash flow. Dalam melakukan analisa, peneliti akan mengambil proksi free cash flow (FCF) yang didasarkan pada penelitian Jensen (1986) yang membuktikan bahwa agency problem akan semakin tinggi pada perusahaan yang memiliki FCF yang besar.

Selain itu, penelitian ini juga memberikan kontribusi dengan meneliti pengaruh variabel moderasi yang memoderasi pengaruh agency cost of free cash flow terhadap tingkat konservatisme yang terdiri dari variabel hutang, pendistribusian kas, kebijakan persistensi kas, dan tata kelola perusahaan. Peran keempat variabel tersebut dalam memoderasi hubungan antara biaya keagenan dengan konservatisme belum diteliti oleh penelitian sebelumnya. Oleh karena itu, penelitian ini dapat memberikan kontribusi dalam pengembangan ilmu pengetahuan dengan melihat apakah keempat variabel tersebut dapat mempengaruhi hubungan antara biaya keagenan dengan konservatisme.

\section{Konservatisme dan Agency Cost of Free Cash Flow}

Teori keagenan memberikan penjelasan bahwa dengan adanya pendelegasian tugas dari pemilik kepada manajer untuk menjalan aktivitas operasional perusahaan, maka muncul permasalahan keagenan yang merupakan dampak dari kecenderungan kedua pihak untuk memaksimalkan keuntungannya (Jensen and Meckling, 1976). Dalam jurnalnya pada tahun 1986, Jensen menyatakan bahwa faktor utama penyebab timbulnya permasalahan keagenan adalah keberadaan dari free cash flow yang substantif dalam perusahaan, atau yang lebih dikenal sebagai agency cost of free cash flow hypothesis. Dan mekanisme yang menurut Jensen (1986) dapat secara efektif mengontrol permasalahan keagenan tersebut adalah penerapan konservatisme pelaporan keuangan.
Menurut Ball dan Shivakumar (2006), konservatisme yang bersifat kondisional merupakan mekanisme yang dapat meningkatkan contracting efficiency dengan meminimalkan insentif manajer untuk mengambil proyek yang secara ex ante memiliki NPV negatif dan memberikan insentif untuk dengan segera meninggalkan investasi yang secara ex post mendatangkan kerugian. Hal tersebut dikarenakan konservatisme akuntansi merupakan mekanisme yang dapat secara ex ante dapat mengontrol keputusan investasi dan secara ex post memfasilitasi pengawasan pengambilan keputusan oleh manajer. Dalam konteks ex ante, konservatisme akuntansi dapat mengontrol keputusan investasi karena dengan menerapkan akuntansi yang konservatif maka manajer akan memiliki insentif yang lebih kecil untuk melakukan investasi dengan NPV yang negatif atau menolak investasi yang memiliki NPV positif. Dengan demikian keputusan investasi yang dilakukan dapat meningkatkan nilai perusahaan. Sedangkan dalam konteks ex post, konservatisme akuntansi dapat memfasilitasi penawasan karena dengan menerapkan akuntansi yang konservatif maka manajer memiliki insentif yang lebih besar untuk meninggalkan investasi yang secara ex post mendatangkan kerugian dan melaporkan kinerjanya secara lebih tepat waktu dengan mengedepankan prinsip kehati-hatian.

Berdasarkan definisi dan pengklasifikasian konservatisme yang telah dijelaskan sebelumnya, menurut Ball dan Shivakumar (2006), pembedaan antara konservatisme yang bersifat unconditional dan conditional sangatlah penting untuk memahami peranan dari konservatisme terhadap efficient contracting dalam perusahaan. Perusahaan disebut konservatif nonkondisional apabila menunda pengakuan pendapatan pada suatu titik waktu atau secara periodik mengurangi labanya secara konstan independen terhadap tingkat laba atau rugi tahun berjalan, misalkan ketika perusahaan memberikan penilaian awal atas suatu asset dan melakukan pembebanan atas depresiasinya dimana kebijakan tersebut akan berdampak pada nilai buku perusahaan dan kebijakan tersebut diambil tidak dengan mempertimbangkan berapa laba berjalan, sehingga tidak meningkatkan contracting efficiency. Sedangkan penerapan konservatisme kondisional Sedangkan konservatiesme kondisional lebih menekankan pada ketepatan waktu pengakuan kerugian (timeliness of loss recognition). Selain itu, Conditional conservatism dapat meningkatkan contracting efficiency dengan meminimalkan insentif manajer untuk mengambil proyek yang secara ex ante memiliki NPV negatif dan memberikan insentif untuk 
dengan segera meninggalkan investasi yang secara ex post mendatangkan kerugian.

Dalam penelitian ini peneliti menggunakan konservatisme yang bersifat conditional (lebih lanjut disebut konservatisme) dikarenakan konservatisme jenis ini lebih menggambarkan contracting efficiency dan lebih dapat digunakan sebagai indikator kualitas laporan keuangan karena dengan penerapan konservatisme yang bersifat kondisional ini maka laporan keuangan perusahaan dapat menggambarkan kondisi perusahaan yang sebenarnya, dimana pengurangan pada laba akuntansi merupakan refleksi dari economic loss yang tengah terjadi.

\section{Pengembangan Hipotesis}

Penelitian ini meneliti apakah perusahaan tipe-J (memiliki agency cost of free cash flow tinggi) akan memiliki tingkat konservatisme yang lebih tinggi di bandingkan perusahaan tipe non-J. Selain itu, peneliti juga ingin menguji efektivitas mekanisme kontrol konservatisme secara relatif terhadap mekanisme kontrol lain seperti hutang, pendistribusian kas, persistensi kas, dan tata kelola perusahaan dengan menjadikan mekanisme kontrol lain tersebut sebagai variable pemoderasi.

Adanya pemisahan kepentingan antara manajer dan pemegang saham memicu permasalah keagenan dimana manajer, tanpa adanya mekanisme pengawasan dan pengikatan yang baik, dapat melakukan ekspropriasi yang pada akhirnya akan merugikan pemegang saham. Untuk menghindari tendensi manajerial seperti itu, Jensen $(1986,2005)$ menekankan pentingnya system pengendalian yang mana pelaporan keuangan yang konservatif dapat menjadi alat pengendalian yang dapat mengurangi perilaku oportunistik manajer dan meningkatkan nilai perusahaan (Watts and Zimmerman, 1990; Watts, 2003a; Ball and Shivakumar, 2006). LaFond dan Watts (2008) mengungkapkan bahwa konservatisme mengalami perkembangan yang sangat pesat dalam merespon kebutuhan pengawasan terkait penilaian manajemen atas peristiwa ekonomi, sehingga dapat menghalangi manajer untuk mengekspropriasi kekayaan shareholder. Ball dan Shivakumar (2006) pun membuktikan bahwa pelaporan keuangan secara konservatif menjadi disinsentif bagi manajer dikarenakan kerugian yang merupakan dampak dari investasi pada proyek yang memiliki NPV negatif akan dibebankan pada periode tersebut. Dalam perusahaan yang memiliki permasalahan keagenan yang tinggi manajer akan memiliki insentif jangka pendek untuk membuat laba tahun berjalan dan ekspektasi atas arus kas menjadi overstated denan tujuan untuk meningkatkan kompensasinya, namun disisi lain pemegang saham dihadapkan oleh resiko eksproprasi dan tidak memiliki kekuatan litigasi yang tinggi untuk mencegah hal tersebut, maka upaya pengendalian melalui pelaporan keuangan yang konservatif menjadi sangat penting. Jensen (1986) juga menyatakan bahwa agency cost of free cash flow akan lebih tinggi pada perusahaan tipe-J, yang mengindikasikan lebih besarnya kebutuhan akan koservatisme. Oleh sebab itu, permintaan atas laporan keuangan yang konservatif yang berfungsi sebagai alat untuk meminimalisir risiko ekspropriasi, akan lebih besar pada perusahaan yang memiliki permasalahan keagenan yang tinggi, terutama pada perusahaan yang memiliki permasalahan keagenan atas FCF, yaitu perusahaan yang memiliki FCF secara substansial tetapi tingkat partumbuhannya rendah. Berdasarkan argument tersebut, peneliti mengembangkan hipotesis sebagai berikut:

H1: Laporan keuangan pada perusahaan tipe-J akan lebih konservatif dibandingkan dengan perusahaan tipe non-J.

Menurut Jensen (1986), hutang juga merupakan salah satu mekanisme yang dapat memitigasi agency cost terkait dengan free cash flow. Hal tersebut dikarenakan kewajiban pembayaran yang ditimbulkan dari kontrak hutang berdampak pada semakin minimnya keberadaan free cash flow yang dapat dieksploitasi oleh manajer. Selain itu, manajer juga dituntut untuk dapat menggunakan sumber daya perusahaan secara efisien agar dapat memenuhi kewajiban pembayaran berupa bunga dan pokok dari hutang tersebut. Menyadari bahwa kebijakan hutang yang diterapkan perusahaan dapat memberikan pengaruh terhadap hubungan antara tingkat agency cost of free cash flow yang dihadapi perusahaan dan tingkat konservatisme dari laporan keuangan yang diterbitkan, peneliti membuat hipotesis sebagai berikut:

H2: Hutang memperlemah hubungan positif tingkat agency cost of free cash flow terhadap tingkat konservatisme laporan keuangan perusahaan.

Terdapat dua jenis pendistribusian kas yang umumnya dilakukan perusahaan, yakni dividen dan stock repurchase. Dengan dilakukannya pendistribusian kas, maka dapat mengurangi FCF di bawah kendali manajemen dan oleh karena itulah dapat meminimkan insentif bagi manajer untuk melakukan investasi yang tidak menguntungkan dan berkontribusi pada peningkatan value perusahaan. 
Dividen cenderung menjadi sebuah long-term commitment ketika sudah diumumkan, yang secara efektif mengikat manajer untuk melakukan pembayaran sejumlah kas di masa mendatang, yang lebih lanjut dapat mengurangi atau memitigasi permasalahan terkait FCF. Jensen (1986) memperluas penelitian Berle dan Means (1932) terkait pemisahan antara kepemilikan dan kontrol, dan berpendapat bahwa perusahaan dengan FCF yang substansial akan memiliki tendensi untuk melakukan overinvest dengan menerima proyek yang memiliki NPV negatif. Jika manajer melakukan overinvesting, peningkatan pada dividen (faktor lain dianggap konstan) akan mengurangi jumlah dana yang dapat digunakan untuk melakukan overinvestment dan dapat meningkatkan nilai pasar dari perusahaan. Hal ini mengindikasikan bahwa terdapat hubungan positif antara pengumuman perubahan dividen dan pergerakan harga saham, sesuai dengan hipotesis atas agency cost of free cash flow yang dipaparkan oleh Jensen (1986). Terkait dengan kebijakan pendistribusian kas dalam bentuk dividen, peneliti membuat hipotesis sebagai berikut:

H3a: Dividen memperlemah hubungan positif tingkat agency cost of free cash flow terhadap tingkat konservatisme laporan keuangan perusahaan.

Grullon dan Michaely (2004) menemukan bahwa perusahaan yang melakukan stock repurchase akan mengalami penurunan yang signifikan pada cadangan kas dalam balance sheet-nya. Mereka pun menemukan bahwa perusahaan yang melakukan stock repurchase cenderung mengurangi current level of capital expenditures dan biaya research and development-nya (R\&D), serta reaksi pasar terhadap pengumuman stock repurchase lebih kuat pada perusahaan yang cenderung overinvest. Penelitian mereka mendukung hipotesis terkait FCF yang diungkapkan oleh Jensen (1986), yang mana dengan dilakukannya stock repurchase oleh perusahaan, maka FCF akan berkurang dan mengurangi eksposur atas penyalahgunaan FCF oleh manajer. Oleh karena itulah peneliti menyusun hipotesis sebagai berikut:

H3b: Stock repurchase memperlemah hubungan positif tingkat agency cost of free cash flow terhadap tingkat konservatisme laporan keuangan perusahaan.

Pada dasarnya tedapat dua motif utama dari persistensi penahanan aset yang bersifat likuid oleh perusahaan (Opler et al. 1999), yakni: (1) Transaction cost motive, perusahaan dapat menghemat biaya transaksi untuk mengumpulkan dana dan tidak perlu melikuidasi aset untuk melakukan pembayaran; dan (2) Precautionary motive, perusahaan menahan dana agar dapat digunakan untuk membiayai aktivitas dan investasi bila sumber pembiayaan lain tidak tersedia atau mahal.

Permasalahan keagenan FCF pada perusahaan tipe-J dapat lebih besar apabila perusahaan menahan sejumlah kas yang berlebih. Dengan tingkat prospek pertumbuhan yang terbatas, perusahaan tipe-J, penahanan kas atau persistensi kas akan memberikan manajer kesempatan untuk melakukan investasi secara fleksibel dan melakukan investasi yang tidak memaksimalkan nilai perusahaan. Pemegang saham pada perusahaan seperti ini akan menjadikan pelaporan keuangan sebagai alat pengendalian, sehingga permintaan akan laporan keuangan yang konservatif akan lebih tinggi. Perusahaan tipe-J yang memegang kas dengan jumlah yang berlebih atau memiliki persistensi kas akan memiliki laporan keuangan yang lebih konservatif karena permintaan pemegang saham yang lebih tinggi untuk mengendalikan manajer dalam meminimalisir permasalahan keagenan. Dengan demikian, kebijakan perusahaan terkait persistensi kas juga dapat mempengaruhi hubungan tingkat agency cost of free cash flow perusahaan terhadap tingkat penerapan prinsip konservatisme laporan keuangan. Oleh karena itulah peneliti membuat hipotesis

H4: Persistensi perusahaan dalam memegang kas memperkuat hubungan positif tingkat agency cost of free cash flow terhadap tingkat konservatisme laporan keuangan perusahaan.

Garcia et al. (2009) mengungkapkan bahwa tata kelola perusahaan yang baik dapat memperkuat hubungan antara tingkat agency cost of free cash flow suatu perusahaan dan tingkat konservatisme laporan keuangan, yang menandakan bahwa pada dasarnya tata kelola dan konservatisme bukanlah bersifat substitusi. Pada perusahaan yang memiliki permasalahan keagenan yang tinggi namun telah mengimplementasikan tata kelola yang baik, maka permintaan pemegang saham akan laporan keuangan yang konservatif akan lebih rendah karena adanya tata kelola telah dapat meminimalisir risiko ekspropriasi. Dengan kata lain tata kelola akan memperlemah pengaruh positif dari agency cost of $\mathrm{FCF}$ terhadap konservatisme. Akan tetapi, penelitian yang dilakukan oleh Bushman dan Piotroski (2006) menunjukkan bahwa ketika earning timeliness rendah, board akan mengadopsi mekanisme tata kelola yang lebih baik sebagai substitusi agat dapat menghasilkan informasi akuntansi yang berkualitas. Artinya, pada perusahaan yang menghadapi permasalahan agensi yang tinggi imple- 
mentasi tata kelola perusahaan akan menuntut manajer untuk menyajikan laporan keuangan yang lebih berkualitas, yaitu yang lebih konservatif. Dengan kata lain peran tata kelola akan memperkuat pengaruh positif dari agency cost of FCF terhadap konservatisme. Dari pemaparan di atas, dapat kita amati bahwa tata kelola dan pelaporan yang konservatif dapat bersifat substitusi ataupun komplementer. Menanggapi hal tersebut, peneliti mencoba menyusun hipotesis yang bersifat netral, yakni:

H5: Tata kelola perusahaan mempengaruhi hubungan positif tingkat agency cost of free cash flow terhadap tingkat konservatisme laporan keuangan perusahaan.

\section{METODE PENELITIAN}

\section{Sumber Data dan Pemilihan Sampel}

Dalam penelitian ini, digunakan data sekunder yang diperoleh melalui datastream. Selain itu juga digunakan Corporate Governance Index, yang diperoleh peneliti melalui Indonesian Institute for Corporate Directorship (IICD). Teknik pemilihan sampel yang digunakan oleh peneliti adalah purposive sampling dengan kriteria-kriteria sebagai berikut: (1) Perusahaan tergolong sebagai perusahaan manufaktur dan terdaftar aktif di BEI selama periode 2007-2008 dan 2010. Tahun 2009 tidak diambil sebagai periode riset karena data terkait dengan indeks tata kelola pada tahun tersebut cukup banyak yang tidak tersedia; (2) Memiliki laporan keuangan tahunan perusahaan yang tersedia lengkap; (3) Memiliki tanggal tutup buku 31 Desember; (4) Menggunakan mata uang rupiah sebagai mata uang pelaporan; (5) Memiliki nilai buku atas ekuitas yang positif; (6) Perusahaan memiliki Corporate Governance Index, yang dipublikasikan oleh IICD; dan (7) Untuk pengujian konservatisme dengan nilai pasar, perusahaan memiliki saham aktif yang diperdagangkan selama tahun 2007-2008 dan 2010.

\section{Model Penelitian}

Sebagaimana telah dijelaskan sebelumnya, penelitian ini bertujuan menguji apakah tingkat konservatisme lebih tinggi pada perusahaan tipe-J (FCF tinggi namun growth rendah) dibandingkan dengan perusahaan tipe non-J. Selanjutnya, hubungan antara variabel independen dan dependen tersebut akan diuji satu per satu dengan menggunakan variabel moderasi seperti hutang, pendistribusian kas, persistensi kas, dan tata kelola perusahaan untuk mengamati perubahan kebutuhan akan konservatisme.
Dalam penelitian ini digunakan dua ukuran konservatisme, yakni ukuran akrual dan nilai pasar. Konservatisme dengan ukuran akrual didasarkan pada model yang disusun oleh Ahmed et al. (2002) sebagai pengembangan dari model yang dipaparkan oleh Givoly dan Hayn (2000). Sementara konservatisme dengan nilai pasar didasarkan pada model Beaver dan Ryan (2000) dalam Wardhani (2008), yang menggunakan rasio book-to-market perusahaan.

Dalam penelitian ini juga digunakan beberapa variabel kontrol. Pertama adalah ukuran perusahaan (SIZE). Menurut Watts dan Zimmerman (1978), ukuran perusahaan dapat mempengaruhi tingkat biaya politis yang dihadapi perusahaan. Semakin besar ukuran perusahaan, biaya politis yang dihadapinya tinggi sehingga mengakibatkan perusahaan terdorong untuk menerapkan prinsip akuntansi yang lebih konservatif dalam rangka mengurangi biaya politis tersebut. Kedua, mengendalikan profitabilitas perusahaan (ROA). Ahmed et al. (2002) menyatakan perusahaan yang memiliki profitabilitas tinggi cenderung untuk menerapkan prinsip akuntansi yang lebih konservatif. Oleh karena itulah profitabilitas harus dimasukkan sebagai variabel kontrol. Dan terkait dengan pengukuran konservatisme dengan nilai pasar, peneliti akan memasukkan juga return saham saat ini (CURR_RET) dan lag return satu tahun (LAG_RET) dalam meregresikan konservatisme dengan ukuran nilai pasar untuk mengontrol efek noise dari pasar.

Berdasarkan penjelasan di atas, berikut adalah model penelitian yang disusun oleh peneliti untuk tiap hipotesis dan tiap ukuran konservatisme:

\section{Model Hipotesis 1}

Untuk menguji pengaruh agency cost terhadap konservatisme, penelitian ini menggunakan variable dummy yang menggolongkan perusahaan menjadi kelompok tipe-J dan tipe non-J. Berdasarkan hal tersebut hipotesis pertama penelitian ini menyatakan bahwa laporan keuangan pada perusahaan tipe-J akan lebih konservatif dibandingkan dengan perusahaan tipe non-J. Untuk menguji hipotesa pertama yang menyatakan perusahaan tipe-J membuat laporan keuangan yang bersifat lebih konservatif dibandingkan perusahaan tipe non-J, peneliti menggunakan model penelitian sebagai berikut:

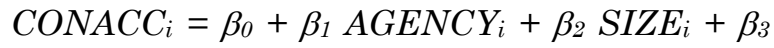
$R O A_{i}+\varepsilon_{i}$

Keterangan:

$C O N A C C_{i}$ Tingkat konservatisme dengan ukuran akrual perusahaan. 
$A G E N C Y_{i}$ Agency Cost of Free Cash Flow yang diukur dengan variable dummy yang mengkelompokkan perusahaan $i$, apakah tergolong sebagai perusahaan tipe-J atau non-J.

$S I Z E_{i}$ Ukuran perusahaan $i$.

$R O A_{i}$ Profitabilitas perusahaan $i$.

\section{Konservatisme dengan nilai pasar}

$$
\begin{aligned}
C O N M K T_{i}= & \beta_{0}+\beta_{1} A G E N C Y_{i}+\beta_{2} S I Z E_{i}+\beta_{3} \\
& R O A_{i}+\beta_{4} C U R R \_R E T_{i}+\beta_{5} \\
& L A G_{-} R E T_{i}+\varepsilon_{i}
\end{aligned}
$$

Keterangan tambahan:

CONMKT $T_{i}$ Tingkat konservatisme dengâ ukuran pasar perusahaan $i$.

CURR_RETi Holding period return satu tahun perusahaan $i$.

$L A G_{-} R E T_{i}$ Return periode sebelumnya.

\section{Model Hipotesis 2}

Pengujian hipotesis kedua bertujuan untuk melihat efek moderasi dari hutang terhadap hubungan antara tingkat agency cost of free cash flow dan tingkat konservatisme laporan keuangan perusahaan, peneliti menggunakan model sebagai berikut:

Konservatisme dengan ukuran akrual

$$
\begin{aligned}
C O N A C C_{i}= & \beta_{0}+\beta_{1} A G E N C Y_{i}+\beta_{2} L E V_{i}+\beta_{3} S I Z E_{i} \\
& +\beta_{4} R O A_{i}+\beta_{5} A G E N C Y_{i} L E V_{i}+\varepsilon_{i}
\end{aligned}
$$

Keterangan tambahan: PERS

$L E V_{i}$ Tingkat hutang (leverage) perusahaan $i$.

Konservatisme dengan nilai pasar

$$
\begin{aligned}
C O N M K T_{i}= & \beta_{0}+\beta_{1} A G E N C Y_{i}+\beta_{2} L E V_{i}+\beta_{3} S I Z E_{i} \\
& +\beta_{4} R O A_{i}+\beta_{5} C U R R \_R E T_{i}+\beta_{6} \\
& L A G_{-} R E T_{i}+\beta_{7} A G E N C Y i L E V i+\varepsilon i
\end{aligned}
$$

\section{Model Hipotesis 3a}

Untuk menguji efek moderasi dari dividen terhadap hubungan pada hipotesis 1 , peneliti menggunakan model sebagai berikut:

\section{Konservatisme dengan ukuran akrual}

$$
\begin{aligned}
C O N A C C_{i}= & \beta_{0}+\beta_{1} A G E N C Y_{i}+\beta_{2} D P O_{i}+\beta_{3} S_{Z} I Z E_{i} \\
& +\beta_{4} R O A_{i}+\beta_{5} A G E N C Y_{i} D P O_{i}+\varepsilon_{i}
\end{aligned}
$$

Keterangan tambahan:

$D P O_{i}$ Besaran dividen yang dibagikan oleh perusahaan $i$.

Konservatisme dengan nilai pasar $\mathrm{CONMKT}_{\mathrm{i}}=\beta_{0}+\beta_{1} A G E N C Y_{i}+\beta_{2} \mathrm{DPO}_{i}+\beta_{3} \mathrm{SIZE}_{i}+\beta_{4}$ $R O A_{i}+\beta 5$ CURR_RET $T_{i}+\beta_{6} L A G_{-} R E T_{i}+$ $\beta_{7} A G E N C Y_{i} D P O_{i}+\varepsilon_{i}$

\section{Model Hipotesis 3b}

Terkait pengujian atas efek moderasi dari stock repurchase terhadap hubungan pada hipotesis 1 , peneliti menggunakan model penelitian sebagai berikut:

\section{Konservatisme dengan ukuran akrual}

$$
\begin{aligned}
\text {CONACC }_{i}= & \beta_{0}+\beta_{1} A G E N C Y_{i}+\beta_{2} \text { REPUR }_{i}+\beta_{3} \\
& \text { SIZE }_{i}+\beta_{4} \text { ROA }_{i}+\beta_{5} A G E N C Y_{i} \\
& \text { REPUR }+\varepsilon_{i}
\end{aligned}
$$

Keterangan tambahan:

Besaran repurchase perusahaan $i$.

\section{Konservatisme dengan nilai pasar}

$$
\begin{aligned}
\text { CONMKT }_{i}= & \beta_{0}+\beta_{1} A G E N C Y_{i}+\beta_{2} R E P U R_{i}+\beta_{3} \\
& S I Z E_{i}+\beta_{4} R O A_{i}+\beta 5 C U R R \_R E T_{i}+ \\
& \beta_{6} L A G_{-} R E T_{i}+\beta_{7} \text { AGENCY } Y_{i} \text { REPUR } \\
& +\varepsilon_{i}
\end{aligned}
$$

\section{Model Hipotesis 4}

Pengujian efek moderasi persistensi kas perusahaan terhadap hubungan pada hipotesis 1 menggunakan model penelitian sebagai berikut:

\section{Konservatisme dengan ukuran akrual}

$$
\begin{aligned}
C O N A C C_{i}= & \beta_{0}+\beta_{1} A G E N C Y_{i}+\beta_{2} P_{E R S_{i}+\beta_{3}} \\
& \text { SIZE }_{i}+\beta_{4} \text { ROA }_{i}+\beta_{5} A G E N C Y_{i} \\
& \text { PERS }_{i}+\varepsilon_{i}
\end{aligned}
$$

Keterangan tambahan:

Persistensi kas perusahaan $i$.

\section{Konservatisme dengan nilai pasar}

$$
\begin{aligned}
C O N M K T_{i}= & \beta_{0}+\beta_{1} A G E N C Y_{i}+\beta_{2} P_{E R} S_{i}+\beta_{3} \\
& S_{Z} E_{i}+\beta_{4} R O A_{i}+\beta 5 C U R R \_R E T_{i}+ \\
& \beta_{6} L A G_{-} \text {RET } T_{i}+\beta_{7} \text { AGENCY } Y_{i} P E R S_{i}+
\end{aligned}
$$
$\varepsilon i$

\section{Model Hipotesis 5}

Dan untuk pengujian efek moderasi dari tata kelola perusahaan terhadap hubungan pada hipotesis 1 , peneliti menggunakan model penelitian sebagai berikut:

\section{Konservatisme dengan ukuran akrual}

$$
\begin{aligned}
\text { CONACC }_{i}= & \beta_{0}+\beta_{1} \text { AGENCY }_{i}+\beta_{2} \text { GOV }_{i}+\beta_{3} \\
& \text { SIZE }_{i}+\beta_{4} \text { ROA }_{i}+\beta_{5} \text { AGENCY }_{i} G O V_{i} \\
& +\varepsilon_{i}
\end{aligned}
$$

Keterangan tambahan: $G O V_{i}$ Tingkat tata kelola perusahaan $i$.

\section{Konservatisme dengan nilai pasar} CONMKT $_{i}=\beta_{0}+\beta_{1}$ AGENCY $_{i}+\beta_{2} G O V_{i}+\beta_{3}$ $S I Z E_{i}+\beta_{4} R O A_{i}+\beta 5$ CURR_RET $T_{i}+$ $\beta_{6} L A G_{-} R E T_{i}+\beta_{7} A_{G E N C Y_{i}} G O V_{i}+$ $\varepsilon_{i}$ 
Operasionalisasi variabel yang digunakan dalam model-model di atas dapat dilihat pada Lampiran 1.

\section{Pengujian Model}

Model-model penelitian di atas akan diuji dengan menggunakan PLS (Pooled Least Square). Dalam pengujian ini juga diuji terpenuhinya asumsi BLUE (Best Linear Unbiased Estimator), yang mana model penelitian harus memenuhi asumsi terdistribusi secara normal, tidak adanya heteroskedastisitas, tidak ada multikolinearitas, dan tidak adanya autokorelasi. Pengujian secara umum dilakukan dengan menggunakan software STATA.

\section{HASIL PENELITIAN DAN PEMBAHASAN}

Sebagaimana telah dijelaskan pada pemilihan sampel, penelitian ini menggunakan sampel perusahaan manufaktur yang terdaftar di BEI dari tahun 2007-2008 dan 2010. Dan berikut ini adalah rincian mengenai statistik deskriptif dari sampel penelitian untuk tiap ukuran konservatisme.

\section{Konservatisme dengan ukuran akrual}

Terkait dengan statistik deskriptif, terdapat dua bagian, yakni statistik deskriptif umum yang membahas mengenai data statistik atas variabelvariabel yang memiliki jumlah sampel yang sama, dan statistik deskriptif khusus, yakni untuk variabel moderasi stock repurchase dan tata kelola perusahaan yang memiliki jumlah sampel yang berbeda. Adapun karakteristik sampel terkait dengan pengukuran konservatisme dengan ukuran akrual dapat dilihat pada Panel A di Lampiran 2. Pada lampiran tersebut, dapat diamati bahwa perusahaan dalam industri manufaktur belum menerapkan prinsip pelaporan keuangan yang bersifat konservatif. Hal ini dapat dilihat dari ratarata konservatisme ukuran akrual (CONACC) yang bernilai negatif. Konservatisme pada dasarnya merupakan akrual yang besifat negatif. Akan tetapi dalam penelitian ini peneliti telah mengalikan nilai akrual dengan negatif satu, sehingga semakin positif akrual maka semakin besar tingkat konservatisme laporan keuangan perusahaan. Statistik juga menunjukkan bahwa rata-rata tingkat leverage yang diukur dengan rasio antara tingkat hutang jangka panjang dengan total asset adalah sebesar $12 \%$. Dan nilai DPO (dividend payout ratio) menunjukkan bahwa perusahaan sampel pada umumnya membagikan $17.6 \%$ laba perusahaan sebagai dividen kepada shareholder.
Selain itu, dapat diamati pula bahwa pada umumnya perusahaan pada industri manufaktur menahan aset perusahaan dalam bentuk kas dan setara kas sebesar 9.6\%. Sementara dari statistik deskriptif khusus dapat diamati bahwa pada umumnya perusahaan tidak melakukan stock repurchase. Terkait dengan pengujian efek moderasi tata kelola perusahaan, dapat diamati dari total 181 sampel, terdapat 91 sampel yang memiliki index CG relatif lebih baik dibandingkan dengan sampel lainnya.

\section{Konservatisme dengan nilai pasar}

Sama halnya dengan statistik deskriptif konservatisme ukuran akrual, pada pengukuran konservatisme dengan nilai pasar pun terbagi menjadi statistik deskriptif umum dan statistik deskriptif khusus, yang mencakup pengujian efek moderasi stock repurchase dan tata kelola perusahaan. Terkait rincian mengenai stastitik deskriptif konservatisme nilai pasar (CONMKT) dapat dilihat pada Panel B di Lampiran 2. Data statistik pada konservatisme nilai pasar menunjukkan hasil yang selaras dengan konservatisme ukuran akrual, yakni perusahaan rata-rata belum menerapkan prinsip laporan keuangan yang konservatif. Data juga menunjukkan bahwa ratarata perusahaan memiliki rasio hutang jangka panjang terhadap total aset sebesar $11.1 \%$. Sementara rasio dividen perusahaan adalah sebesar 17\% dari labanya, dan data pun menunjukkan bahwa umumnya perusahaan menahan kas sebesar $10.3 \%$ dari total aset yang dimilikinya. Selain itu, terkait statistik deskriptif khusus, pengujian dengan menggunakan konservatisme nilai pasar pun menunjukkan bahwa perusahaan sampel rata-rata tidak melakukan stock repurchase. Terkait dengan tata kelola perusahaan, dari total 171 sampel, terdapat 88 sampel yang memiliki tata kelola relatif lebih baik.

\section{Analisis Pengaruh Agency Cost of Free Cash Flow terhadap Tingkat Konservatisme}

Dalam menganalisa pengaruh agency cost of free cash flow terhadap tingkat konservatisme laporan keuangan, maka dilakukan pengujian dengan menggunakan persamaan pada model hipotesis 1 di atas. Hasil pengujian dapat dilihat pada Panel A di Lampiran 3 untuk konservatisme ukuran akrual dan Panel B untuk konservatisme nilai pasar pada lampiran 3. Dari tabel tersebut dapat diamati F-test menunjukkan bahwa secara keseluruhan variabel independen dalam model berpengaruh signifikan terhadap variabel dependen konservatisme. Dan dapat dilihat angka R- 
square menunjukkan nilai sebesar $13.83 \%$ pada konservatisme ukuran akrual, yang berarti $13.83 \%$ variasi dari variabel dependen dapat dijelaskan oleh variabel-variabel independennya. Sementara $\mathrm{R}$-square atas pengujian dengan konservatisme nilai pasar menunjukkan angka sebesar $13.66 \%$.

Hasil uji t-test pada kedua ukuran konservatisme menunjukkan bahwa terdapat hubungan positif signifikan antara tingkat agency cost of free cash flow perusahaan terhadap tingkat konservatisme laporan keuangan perusahaan. Hal ini selaras dengan hipotesis 1 yang telah disusun peneliti. Hasil penelitian menunjukkan bahwa perusahaan tipe-J yaitu perusahaan yang memiliki permasalahan keagenan dari FCF yang tinggi akan lebih konservatif. Hasil ini senada dengan pernyataan Jensen (1986) bahwa perusahaan yang memiliki permasalahan keagenan yang besar terkait keberadaan free cash flow dalam perusahaan akan menerapkan sistem yang dapat mengatasi permasalahan tersebut, salah satunya melalui penerapan laporan keuangan yang lebih konservatif. Dan LaFond dan Watts (2008) mengungkapkan bahwa konservatisme merupakan mekanisme yang berkembang secara pesat dalam merespon kebutuhan pengawasan oleh shareholder, yang didukung oleh pernyataan Ball dan Shivakumar (2006) yang membuktikan konservatisme menimbulkan disinsentif bagi manajer untuk menyalahgunakan free cash flow yang terdapat di perusahaan.

Selain itu, pada kedua ukuran konservatisme, ditemukan bahwa SIZE memiliki hubungan positif dan signifikan. Hal ini selaras dengan pernyataan Watts dan Zimmerman (1978) yang menyatakan bahwa semakin besar ukuran perusahaan, maka biaya politis yang dihadapinya semakin besar pula dan mendorong perusahaan untuk menerapkan prinsip pelaporan keuangan yang konservatif. Sementara hasil pengujian menunjukkan arah pengaruh ROA yang terbalik dengan ekspektasi arah, yakni ROA berpengaruh secara negatif dan signifikan pada level $1 \%$, bertentangan dengan Ahmed et al, (2002) Hasil penelitian ini justru menunjukkan bahwa semakin tinggi tingkat profitabilitas perusahaan maka laporan keuangan yang dihasilkan akan memiliki tingkat konservatisme yang lebih rendah. Perbedaan hasil ini mungkin menunjukkan bahwa perusahaan dengan profitabilitas yang tinggi telah mencapai efficient contracting (seperti misalkan dari segi kontrak kompensasi dan kontrak hutang yang telah mencapai tingkat yang ditargetkan) sehingga pelaporan yang konservatif mengalami penurunan dalam aspek permintaannya. Dan secara spesifik untuk variabel kontrol konservatisme nilai pasar, hasil regresi menunjukkan bahwa hanya CURR_RET yang berpengaruh signifikan.

\section{Analisis Efek Moderasi Kebijakan Hutang}

Efek moderasi dari kebijakan hutang dapat diperoleh dengan meregresikan model hipotesis 2 di atas. Adapun hasil regresi hipotesis 2 dapat dilihat pada Lampiran 3, yang mana Panel A untuk konservatisme ukuran akrual, dan Panel B untuk konservatisme nilai pasar. Dari hasil regresi dengan menggunakan kedua ukuran konservatisme, hasil pengujian F-test menunjukkan bahwa secara keseluruhan variabel independen dalam model berpengaruh signifikan. Dan dapat dilihat angka $\mathrm{R}$-square menunjukkan nilai sebesar $13.44 \%$ pada konservatisme ukuran akrual, yang berarti $13.44 \%$ variasi dari variabel dependen dapat dijelaskan oleh variabel-variabel independennya. Sementara R-square atas pengujian dengan konservatisme nilai pasar menunjukkan angka sebesar $13.73 \%$.

Hasil uji t-test kedua ukuran menunjukkan bahwa sebagai variabel pemoderasi, hutang tidak berpengaruh terhadap hubungan positif antara tingkat agency cost of free cash flow dan tingkat konservatisme laporan keuangan perusahaan, yang bertentangan dengan hipotesis 2 yang telah disusun oleh peneliti. Hasil regresi yang menunjukkan bahwa hutang tidak berpengaruh terhadap hubungan antara tingkat agency cost of free cash flow dan tingkat konservatisme laporan keuangan. Hasil penelitian ini menunjukkan bahwa kreditur tidak mempengaruhi permintaan pemegang saham atas laporan keuangan yang lebih konservatif. Hasil ini disebabkan karena kreditur memiliki kejelasan kontrak dengan perusahaan sehingga risiko litigasi yang dihadapi bank jauh lebih kecil dari yang dimiliki oleh pemegang saham. Terutama dalam konteks Indonesia yang hutang perusahaan lebih didominasi oleh hutang bank. Misalkan bank memiliki hak mendahului atas asset perusahaan apabila perusahaan mengalami gagal bayar. Oleh karenanya bank biasanya lebih memonitor kinerja perusahaan melalui ketaatan perusahaan dalam memenuhi covenant hutang. Oleh karena itu tingkat hutang tidak mempengaruhi pengaruhi agency cost of FCF terhadap konservatisme karena permintaan pemegang saham atas laporan keuangan yang lebih konservatif tidak berubah seiring dengan peningkatan hutang perusahaan.

\section{Analisis Efek Moderasi Kebijakan Dividen}

Hasil regresi dari efek moderasi kebijakan dividen dapat diamati pada Lampiran 3. Dari hasil regresi dapat diamati bahwa F-test menunjukkan secara keseluruhan variabel independen dalam model berpengaruh signifikan. Dan R-square me- 
nunjukkan angka sebesar $14.02 \%$ untuk konservatisme ukuran akrual, yang berarti $14.02 \%$ variasi dari variabel dependen dapat dijelaskan oleh variabel-variabel independennya. Sementara $\mathrm{R}$-square atas pengujian dengan konservatisme nilai pasar menunjukkan angka sebesar $13.36 \%$.

Hasil t-test untuk hipotesis 3a dalam pada kedua ukuran menunjukkan bahwa dividen tidak mempengaruhi hubungan antara tingkat agency cost of free cash flow dan tingkat konservatisme laporan keuangan perusahaan. Hasil ini menunjukkan bahwa hipotesis 3a tidak dapat diterima. Selain dari mekanisme untuk menurunkan konflik keagenan dimana dengan dibagikannya deviden maka FCF yang tersedia bagi manajer semakin berkurang sehingga kesempatan utk ekspropriasi menjadi lebih kecil dan konflik antara pemegang saham dan pemegang hutang juga menjadi lebih kecil, dividen juga dapat berperan sebagai alat untuk penyampaian sinyal, seperti yang dijelaskan dalam signaling theory. Perusahaan yang memiliki kinerja baik dapat memberikan sinyal salah satunya melalui pembagian dividen yang seringkali dijadikan indikator kinerja yang baik. Tidak signifikannya pengaruh dividen sebagai variable moderasi dari hubungan antara agency cost of FCF dan konservatisme menunjukkan bahwa permintaan pemegang saham atas laporan keuangan yang lebih konservatif untuk mengendalikan permasalahan keagenan tidak dipengaruhi oleh tingkat dividen perusahaan, karena dividen yang dibayarkan perusahaan lebih digunakan sebagai alat pensinyalan bukan sebagai mekanisme untuk meminimalisir permasalahan keagenan. Dengan digunakan dividen sebagai alat pensinyalan, maka perubahan tingkat dividen yang dibagikan tidak mempengaruhi permintaan atas laporan keuangan yang lebih konservatif.

\section{Analisis Efek Moderasi Stock Repurchase}

Hasil regresi dari efek moderasi stock repurchase dapat diamati pada Lampiran 3. Pada tabel tersebut, dapat diamati bahwa F-test menunjukkan secara keseluruhan variabel independen dalam model berpengaruh signifikan. Dan Rsquare menunjukkan angka sebesar $14.64 \%$ untuk konservatisme ukuran akrual, yang berarti 14.64\% variasi dari variabel dependen dapat dijelaskan oleh variabel-variabel independennya. Sementara $\mathrm{R}$-square atas pengujian dengan konservatisme nilai pasar menunjukkan angka sebesar $14.92 \%$.

Dari hasil t-test, dapat diamati bahwa stock repurchase tidak berpengaruh terhadap hubungan pada hipotesis 1 ketika diuji dengan menggunakan konservatisme ukuran akrual. Hal tersebut dikarenakan stock repurchase bersifat fleksibel dan cenderung diterapkan oleh perusahaan dengan perlindungan investor yang lemah (Harford et al., 2008). Selain itu, di Indonesia sendiri masih sedikit perusahaan yang menerapkan stock repurchase dikarenakan dibutuhkan biaya yang besar. Tercatat dari tahun 2001-2007 hanya terdapat 30 kali pengumuman terkait stock repurchase. Akan tetapi, pengujian dengan konservatisme nilai pasar menunjukkan hasil yang sesuai dengan hipotesis dimana stock repurchase memperlemah pengaruh positif agency cost of FCF terhadap konservatisme. Hal ini dimungkinkan terjadi karena stock repurchase mengakibatkan cadangan kas perusahaan mengalami penurunan secara signifikan (Grullon dan Michaely, 2004), yang membuat pasar akan melakukan penyesuaian terhadap penilaian value perusahaan.

\section{Analisis Efek Moderasi Persistensi Kas}

Terkait pengujian efek moderasi persistensi kas, hasil regresi dapat diamati pada Lampiran 3. Pada kedua tabel, hasil F-test menunjukkan secara keseluruhan variabel independen dalam model berpengaruh signifikan. Dan R-square menunjukkan angka sebesar $16.11 \%$ untuk konservatisme ukuran akrual, yang berarti $16.11 \%$ variasi dari variabel dependen dapat dijelaskan oleh variabel-variabel independennya. Sementara $\mathrm{R}$-square atas pengujian dengan konservatisme nilai pasar menunjukkan angka sebesar 13.39\%.

Berdasarkan hasil t-test, dapat dilihat bahwa persistensi kas perusahaan tidak mempengaruhi hubungan pada hipotesis 1 untuk kedua ukuran konservatisme. Hal tersebut dikarenakan dari data statistik, rata-rata perusahaan pada sampel memiliki rasio PERS sebesar 9.4\% sementara rasio hutang jangka panjang terhadap total asetnya mencapai rata-rata $14.6 \%$. Oleh karena itulah kebijakan perusahaan untuk secara persisten menahan kas dimungkinkan untuk mengantisipasi ketidakmampuan pelunasan hutang jangka panjang yang dimilikinya, sehingga PERS tidaklah relevan sebagai mekanisme kontrol terkait agency cost of free cash flow.

\section{Analisis Efek Moderasi Tata Kelola Perusa- haan}

Pada Lampiran 3, dapat diamati pula hasil regresi dari variabel pemoderasi tata kelola perusahaan. Pada tabel tersebut dapat diamati bahwa F-test menunjukkan secara keseluruhan variabel independen dalam model berpengaruh signifikan. Dan R-square menunjukkan angka sebesar $18.66 \%$ untuk konservatisme ukuran akrual, yang berarti $18.66 \%$ variasi dari variabel dependen 
dapat dijelaskan oleh variabel-variabel independennya. Sementara $\mathrm{R}$-square atas pengujian dengan konservatisme nilai pasar menunjukkan angka sebesar $26.65 \%$.

Hasil t-test menunjukkan bahwa tata kelola perusahaan tidak mempengaruhi hubungan pada hipotesis 1 . Hal tersebut dikarenakan secara ratarata perusahaan di Indonesia masih belum menerapkan tata kelola perusahaan yang baik. Dari data IICD, tercatat rata-rata tingkat tata kelola perusahaan manufaktur di Indonesia berada pada performance level fair, yakni pada rentang $60 \%-79 \%$. Dengan demikian, tata kelola perusahaan belum dapat menjadi mekanisme kontrol yang efektif dalam mengatasi agency cost of free cash flow.

\section{KESIMPULAN DAN SARAN}

Penelitian ini memiliki dua tujuan. Pertama adalah untuk mengetahui apakah perusahaan dengan agency cost of free cash flow tinggi (perusahaan tipe-J) akan memiliki laporan keuangan yang bersifat lebih konservatif dibandingkan perusahaan tipe non-J. Sedangkan tujuan kedua dari penelitian ini adalah untuk melihat pengaruh efek moderasi hutang, dividen, share repurchase, persistensi perusahaan dalam menahan kas, dan tata kelola perusahaan terhadap hubungan antara tingkat agency cost of free cash flow dan tingkat konservatisme laporan keuangan perusahaan. Dalam rangka mencapai tujuan penelitian tersebut, maka peneliti menyusun model penelitian yang menghubungkan tingkat konservatisme laporan keuangan perusahaan, tingkat agency cost of free cash flow, serta juga turut memasukkan komponen variabel moderasi dalam model.

Dalam penelitian ini digunakan dua ukuran konservatisme, yakni ukuran akrual dan nilai pasar. Hasil penelitian menunjukkan bahwa perusahaan dengan agency cost of FCF tinggi memiliki laporan keuangan yang lebih konservatif. Akan tetapi, terkait pengujian dengan variabel moderasi, hasil penelitian menunjukkan bahwa hubungan antara agency cost of FCF dengan konservatisme tersebut tidak dipengaruhi oleh variabel moderasi yang diuji dalam penelitian ini. Seluruh model pengujian dengan menggunakan variabel moderasi menunjukkan bahwa tidak terdapat pengaruh variabel pemoderasi hutang, dividen, share repurchase, persistensi perusahaan dalam menahan kas, serta tata kelola perusahaan terhadap hubungan antara tingkat agency cost of free cash flow dan tingkat konservatisme laporan keuangan pada perusahaan tipe-J dan tipe non-J.
Penelitian ini memberikan implikasi pada ilmu pengetahuan terkait pemahaman atas mekanisme kontrol atas permasalahan keagenan yang timbul sebagai akibat dari keberadaan free cash flow dalam perusahaan. Kesimpulan dari penelitian ini mengimplikasikan bahwa konservatisme merupakan mekanisme kontrol atas agency cost of free cash flow yang relatif lebih efektif dibandingkan mekanisme kontrol hutang, pendistribusian kas, penahanan kas, dan tata kelola perusahaan. Selain itu penelitian ini juga memberikan implykasi bagi regulator. Melalui penelitian ini, diketahui bahwa free cash flow merupakan informasi penting yang dapat menimbulkan masalah keagenan. Oleh karena itulah, regulator dapat menuntut pengungkapan atas free cash flow dalam laporan keuangan perusahaan agar shareholder dapat menilai risiko keagenan dalam perusahaan. Selama ini pengungkapan atas free cash flow bersifat voluntary. Mengingat pentingnya informasi free cash flow tersebut, maka regulator dapat membuat aturan untuk memasukkan informasi free cash flow tersebut dalam pengungkapan yang bersifat mandatori dalam laporan tahunan. Sedangkan untuk pemegang saham penelitian ini dapat memberikan wawasan bagi pemegang saham untuk dapat lebih menuntut perusahaan agar menyusun laporan dengan konservatif atas berinvestasi pada perusahaan yang konservatif untuk menghindari risiko ekspropriasi.

Peneliti menyadari bahwa penelitian ini memiliki beberapa keterbatasan, yakni:

(1) Pendeknya rentang waktu periode penelitian, yakni tahun 2007-2008 dan 2010. Padahal menurut Richardson et al., (2005), akrual memiliki kecenderungan untuk membalik pada periode satu hingga dua tahun, sehingga dalam perhitungan konservatisme dengan ukuran akrual peneliti merata-ratakan nilai konservatisme selama tiga tahun. Dengan rentang waktu yang relatif pendek, maka dimungkinkan hasil penelitian yang diperoleh kurang menunjukkan realita yang sebenarnya. Oleh karena itulah penelitian berikutnya dapat memperbaikinya dengan mengambil periode penelitian yang lebih panjang.

(2) Penelitian ini hanya menggunakan dua ukuran konservatisme, yakni ukuran akrual dan nilai pasar. Padahal banyak model penelitian lainnya seperti model Basu (1997) yang menggunakan pergerakan harga saham ataupun model discretionary accrual. Oleh karena itulah, penelitian berikutnya dapat mengembangkan penelitian ini dengan menggunakan model lain untuk melihat apakah hasil yang diperoleh sama dengan temuan peneliti atau tidak. 


\section{DAFTAR PUSTAKA}

Ahmed, A. S., Billings, K. B., Morton, M. R., and Stanford-Harris, M. (2002). The Role of Accounting Conservatism In Mitigating Bondholder-Shareholder Conflicts over Dividend Policy and in Reducing Debt Costs. The Accounting Review, 77(4), 867-890.

Ray, B., Robin, A., and Wu, J. S. (2003). Incentives Versus Standards: Properties of Accounting Income In Four East Asian Countries. Journal of Accounting and Economic, 36(1-3), 235-270.

Ball, R. A. Y. and Shivakumar, L. (2006). The Role of Accruals in Asymmetrically Timely Gain and Loss Recognition. Journal of Accounting Research, 44(2), 207-242.

Basu, S. (1997). The Conservatism Principle and The Asymmetric Timeliness Of Earnings. Journal of Accounting and Economics, 24(1), 3-37.

Beekes, W., Pope, P., and Young, S. 2004. The Link Between Earnings Timeliness, Earnings Conservatism and Board Composition: Evidence From The UK. Corporate Governance, 12(1), 47-59.

Berle, A. A. and Means, G. C. (1932). The Modern Corporation and Private Property. New York: Harcourt, Brace \& World.

Bushman, R. M. and Piotroski, J. D. (2006). Financial Reporting Incentives for Conservative Accounting: The Influence of Legal and Political Institutions. Journal of Accounting and Economics, 42(1-2), 107-148.

Crutchley, C. E. and Hansen, R. S. (1989). A Test of the Agency Theory of Managerial Ownership, Corporate Leverage, and Corporate Dividends. Financial Management, 18(4), Winter, 36-46.

Dechow, P. M., Richardson, S. A., and Sloan, R. G. (2008). The Persistence and Pricing of The Cash Component of Earnings. Journal of Accounting Research, 46(3), 53-566.

Dittmar, A., Mahrt-Smith, J., and Servaes, H. (2003). International Corporate Governance and Corporate Cash Holdings. Journal of Financial and Quantitative Analysis, 38(1), 111-133.

Easterbrook, F. H. (1984). Two Agency-Cost Explanations of Dividends. The American Economic Review. 74(4), 650-659

García Lara, J., García Osma, B., and Penalva, F. (2009). Accounting Conservatism and Corporate Governance. Review of Accounting Studies, 14(1), 161-201.

Givoly, D. and Hayn, C. (2000). The Changing Time-Series Properties of Earnings, Cash
Flows and Accruals: Has Financial Reporting Become More Conservative? Journal of Accounting and Economics, 29, 287-320.

Grullon, G., Michaely, R. (2004). The Information Content of Share Repurchase Programs. The Journal of Finance, 59(2), 651-680.

Harford, J., Mansi, S. A., and Maxwell, W. F. (2008). Corporate Governance and Firm Cash Holdings in The US. Journal of Financial Economics, 87(3), 535-555.

Holthausen, W. R. and Watts, L. R. (2001). The Relevance of The Value-Relevance Literature for Financial Accounting Standard Setting. Journal of Accounting \& Economics, 31(1-3), 3-75.

Jensen, M. C. (1986). Agency Costs of Free Cash Flow, Corporate Finance and Takeovers. The American Economic Review, 76(2), 323-329.

Jensen, M. C. (1989). Eclipse of The Public Corporation. Harvard Business Review, 67, 61-74.

Jensen, C. M. (2005). Agency Costs of Overvalued Equity. Financial Management, 34(1), 5-19.

Jensen, M. C. and Meckling. W. H. (1976). Theory of The Firm: Managerial Behavior, Agency Costs and Ownership Structure, Journal of Financial Economics. 3(4), 305-360.

Kose John dan Anzhela Knyazeva (2006). Payout Policy, Agency Conflicts, and Corporate Governance. www.ssrn.com

La Porta, R., F. Lopez-De-Silanes, A. Shleifer, and R. Vishny (2000), Agency Problems and Dividend Policies around The World, Journal of Finance, 55 (1), 1-33.

LaFond, R. and Watts, R. (2008). The Information Role of Conservatism. The Accounting Review, 83(2), 447-478.

LaFond, R. and Roychowdhury, S. (2008). Managerial Ownership and Accounting Conservatism. Journal of Accounting Research, 46(1), 101135.

Opler, T., Pinkowitz, L., Stulz, R., and Williamson, R. (1999). The Determinants and Implications of Corporate Cash Holdings. Journal of Financial Economics, 52(1), 3-46.

Richardson, S. A., Sloan, R. G., Soliman, M. T., Tuna, I. A. (2005). Accrual Reliability, Earnings Persistence and Stock Prices. Journal of Acoounting and Economics, 39, 437-485.

Shleifer, A., \& Vishny, R. W. (1997). A Survey of Corporate Governance. The Journal of Finance, 52(2), 737-783.

Wardhani, R., Utama, S., Rossieta, H. (2015). The Effect of Governance System and Degree of Convergence to IFRS on The Quality of Financial Reporting: Evidence From Asia. Corporate Ownership and Control, 12(4), 409423. 
Wardhani, R. (2008). Tingkat Konservatisme Akuntansi di Indonesia dan Hubungannya dengan Karakteristik Dewan sebagai Salah Satu Mekanisme Corporate Governance. Working Paper, Fakultas Ekonomi Universitas Indonesia.

Watts, L. R. (2003a). Conservatism in Accounting part I: Explanations and Implications. Accounting Horizons, 17(3), 207-221
Watts, L. R. (2003b). Conservatism in Accounting Part II: Evidence and Research Opportunities. Accounting Horizons, 17(4), 287-301.

Watts, R. L, and Zimmerman, J. L. (1978). Towards a Positive Theory of the Determination of Accounting Standards. The Accounting Review, 53(1), 112-134.

Watts, R. L., \& Zimmerman, J. L. (1990). Positive Accounting Theory: A Ten Year Perspective. The Accounting Review, 65(1), 131-156.

\section{LAMPIRAN 1:}

\section{DEFINISI OPERASIONAL VARIABEL}

\begin{tabular}{ll}
\hline Nama Variabel & Operasionalisasi Variabel \\
\hline Konservatisme & 1. Ukuran Akrual \\
& $\begin{array}{l}\text { Rata-rata dari laba sebelum extra-ordinary items dikurangi dengan arus kas operasi } \\
\text { ditambah biaya depresiasi/amortisasi. Selanjutnya angka tersebut dikalikan dengan } \\
\text { (1) dan dideflasikan dengan rata-rata total aktiva. Nilai yang digunakan sebagai } \\
\text { proksi adalah nilai rata-rata selama tiga tahun dengan nilai tengah pada periode t. } \\
\text { 2. Ukuran Nilai Pasar } \\
\text { Rasio book-to-market perusahaan. Nilai tersebut dikali dengan (-1) agar nilai positif } \\
\text { mencerminkan tingkat konservatisme yang lebih tinggi. }\end{array}$ \\
\hline Agency Cost of Free Cash Flow & $\begin{array}{l}\text { Variabel dummy, nilai = 1 (0) jika FCF berada di atas (di bawah) nilai median industri } \\
\text { dan GROWTH berada di bawah (di atas) nilai median. }\end{array}$ \\
\hline Ukuran Perusahaan & Logaritma natural dari nilai pasar ekuitas. \\
\hline Profitabilitas & Laba sebelum extra-ordinary items dibagi dengan total aset. \\
\hline Leverage & Total hutang jangka panjang dibagi dengan total aset perusahaan. \\
\hline Dividen Payout & Persentase dari laba perusahaan yang dibagikan dalam bentuk dividen \\
\hline Stock Repurchase & $\begin{array}{l}\text { Nilai bersih dari stock repurchase setelah dikurangi stock issuance, kemudian dibagi } \\
\text { dengan laba sebelum extra-ordinary items. }\end{array}$ \\
\hline Persistensi Kas & $\begin{array}{l}\text { Rata-rata rasio kas dan setara kas, yakni jumlah total rasio kas dan setara kas } \\
\text { periode t dan t-1 dibagi } 2 .\end{array}$ \\
\hline Tata Kelola Perusahaan & $\begin{array}{l}\text { Variable dummy, yang mana memiliki nilai = 1 (0) jika perusahaan memiliki CG } \\
\text { index di atas (di bawah) nilai median industri. }\end{array}$ \\
\hline
\end{tabular}



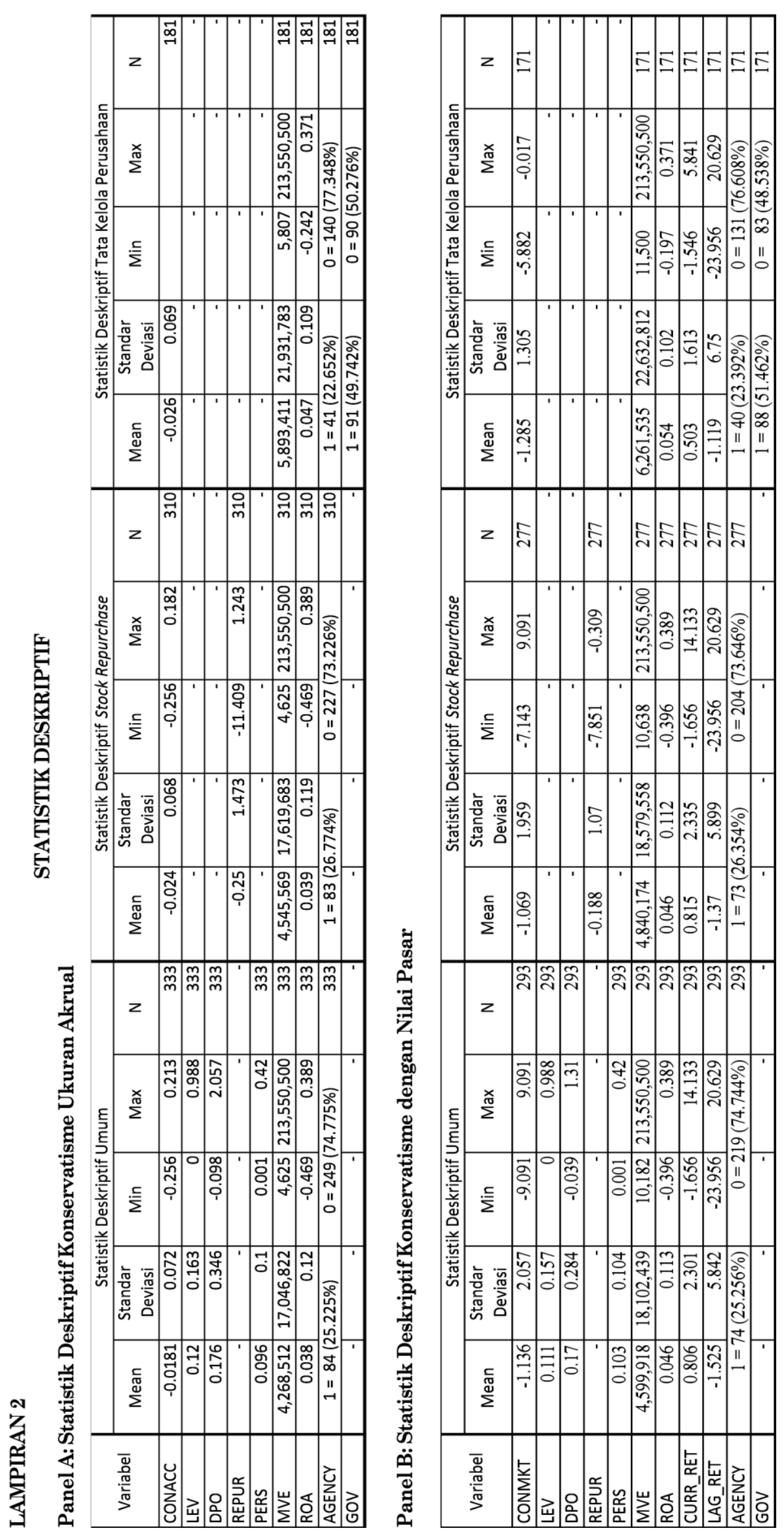

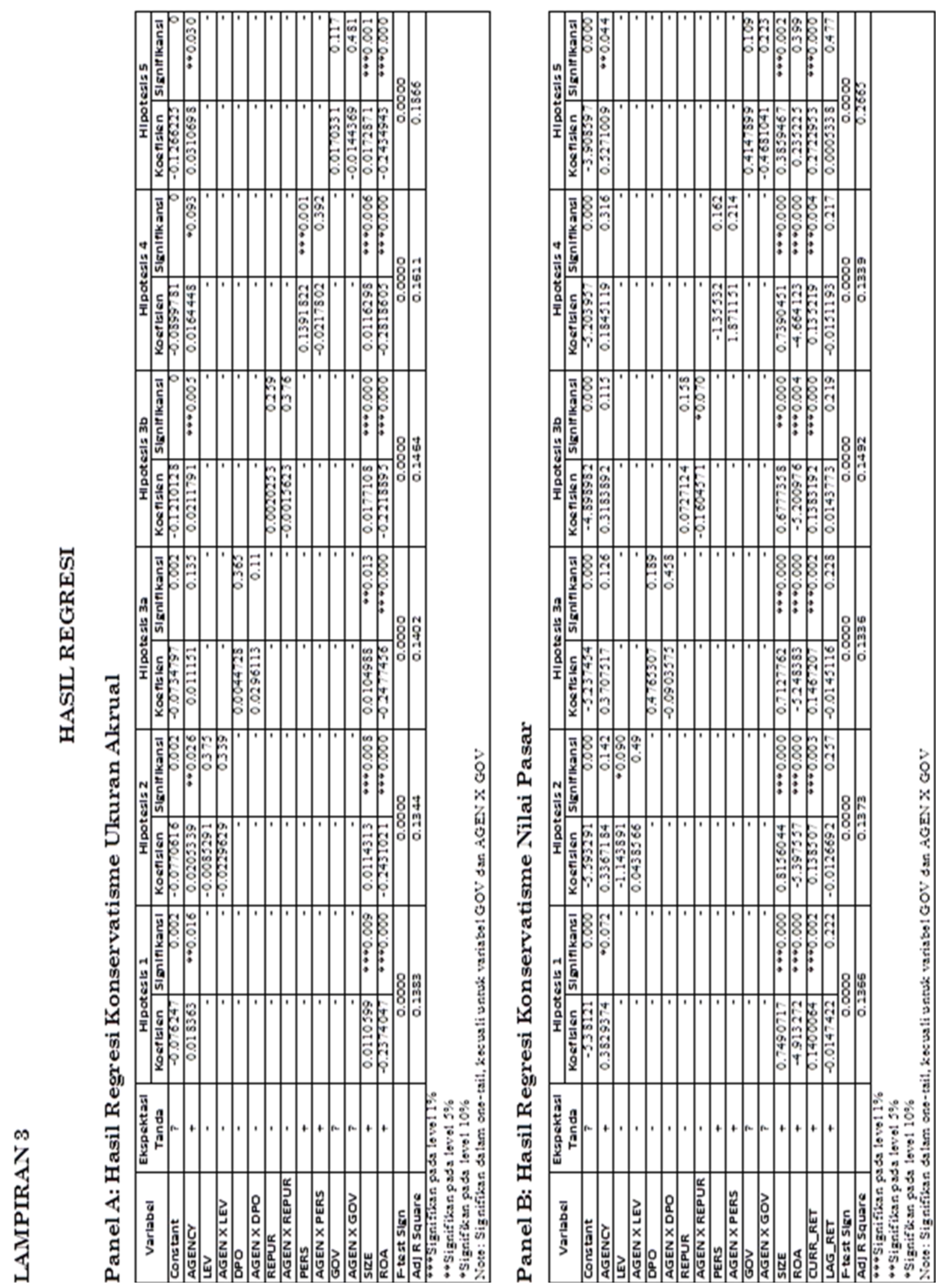